Article

\title{
The Financing of Renewable Energy Sources and the Level of Sustainable Development of Poland's Provinces in the Area of Environmental Order
}

\author{
Piotr Siemiątkowski ${ }^{1, *}{ }^{\oplus}$, Patryk Tomaszewski ${ }^{1}\left(\mathbb{D}\right.$, Joanna Marszałek-Kawa ${ }^{1}(\mathbb{D}$ and \\ Janusz Gierszewski ${ }^{2}$ (D) \\ 1 Faculty of Political Science and Security Studies, Nicolaus Copernicus University in Torun, \\ ul. Stefana Batorego 39L, 87-100 Toruń, Poland; patrykt@umk.pl (P.T.); kawaj@umk.pl (J.M.-K.) \\ 2 Institute of Security and Management, Pomeranian University in Słupsk, ul. Krzysztofa Arciszewskiego 22A, \\ 76-200 Słupsk, Poland; janusz.gierszewski@apsl.edu.pl \\ * Correspondence: piotrs@umk.pl
}

Received: 17 September 2020; Accepted: 22 October 2020; Published: 26 October 2020

check for updates

\begin{abstract}
The overall purpose of this study is to evaluate the impact of financing renewable energy sources on the assessment of sustainable development in Poland's provinces. There are also two detailed objectives: (1) define how Polish policies are being passed on to local authorities; (2) realize a Poland's provinces ranking, taking into account the indicators of sustainable development, thanks to the taxonomic measure of development in the area of environmental order. This study deals with the taxonomic assessment of local sustainable development in the local administration units of Poland. To this end, the methods of linear ordering were applied for the assessment of the level of objects differentiation with the use of a closed set of statistical features. The presented analysis proved that the taxonomic distances between synthetic measures for particular provinces are considerable. The highest values of the integrated measure in 2018 were obtained by the following provinces: Podlaskie, Subcarpathian and Lubusz. It is noteworthy to point to the big changes in the ranking between 2018 and 2016. The cluster analysis showed some progress in achieving the goals of sustainable development. The group of provinces with an average level of sustainable development in 2018 included six provinces compared to two provinces in 2016. Removing one indicator from the integrated measure (the financing of renewable energy sources (RES)) led to a moderate increase in the integrated measure across all the provinces. This implies that, on average, the financing of renewable energy sources exerts increasingly smaller impacts on the level of sustainable development in Poland.
\end{abstract}

Keywords: renewable energy sources; sustainable development; Poland's provinces

\section{Introduction}

The contemporary world is facing a great number of challenges caused by climate change as a result of human activity [1-3]. One of the key solutions for slowing down the pace of the ongoing changes in environmental order is altering the energy policy [4]. Notably, this is about changing the pattern of resource supplies, searching for alternative and renewable energy sources, and developing state-of-the-art technological solutions for enhancing energy efficiency [5]. Indisputably, both international and national policies ought to promote the development of the renewable energy sources (RES) sector [6].

The strategic documents of the European Union (EU) clearly indicate the need for the intensification of this process across all EU member states [7]. In Poland, this policy is being carried out at a few levels, i.e., government, local government, and by giving aid to non-governmental organizations. An important tool of this policy is providing financial aid to projects aiming at increasing the share 
of RES in the country's energy balance. This type of activity is consistent with the key concept of sustainable development, one particular element of which is environmental order.

Maintaining sustainable social-economic development is one of the major challenges of the contemporary world [8,9]. In 1983, the notion of sustainable development was defined by the World Commission on Environment and Development (also known as the G. Brundtland Commission). Under this definition, sustainable development is development that meets the needs of the present without compromising the ability of future generations to meet their own needs. This type of development involves environmental, economic and social aspects [10].

The overall aim of this study is to evaluate the impact of financing RES on the assessment of sustainable development in Poland's provinces in the area of environmental order.

The above presented analysis will be conducted with the use of the taxonomic multidimensional analysis. This method offers some significant advantages over traditional statistical methods of data aggregation (the arithmetic mean, the geometric mean, or Leontief's production function) [11]. For instance, the method allows avoiding situations in which the researched objects take a distant place in the global ranking due to a single weak indicator despite high values of all the other indicators. There are also two detailed objectives:

(1) Define how Polish policies are being passed on to local authorities (specific objective one);

(2) Realize a Poland's provinces ranking, taking into account the indicators of sustainable development, thanks to the taxonomic measure of development in the area of environmental order (specific objective two).

For the purpose of this study, the following research questions were formulated:

Q1: Taking into account the selected indicators (concerning the objectives of sustainable development in the area of environmental order) from the main statistical office, are there any significant disparities across provinces?

Q2: To what extent does the expenditure of local governments (provinces) on financing RES impact the sustainable development of Poland's provinces in the area of environmental order?

During the research procedure, the following hypotheses were formulated:

Hypotheses 1. There are significant disparities in the implementation of tasks concerning sustainable development in the area of environmental order across particular provinces.

Hypotheses 2. Pursuant to the strategy of the government on climate protection (forced by EU guidelines), the financing of RES by local governments has a big influence on the sustainable development of Poland's provinces in the area of environmental order.

The analysis features a number of advantages. First, it shows progress (or no progress) in implementing the goals of sustainable development by Polish provinces (between 2016 and 2018). Second, a procedure was applied under which, in the second phase of the analysis, one of the indicators was removed from the integrated measure (i.e., the financing of renewable energy sources). This operation made it possible to determine the extent to which the financing of RES impacts the overall assessment of sustainable development in particular administration units. Third, the available analyses concern different sets of indicators, different time periods and somewhat different methods $[12,13]$. The number of the methods in the multidimensional analysis is huge, with the Hellwig method relatively rarely used in English language publications.

\section{Theoretical Background}

\subsection{Environmental Policy Integration (EPI)}

According to Adelle and Russel the dynamic climate changes observed in recent years have made the implementation of the climate policy integration (CPI) concept the priority task. The strategy of preventing, counteracting and adapting to climate change is a significant challenge that state governments and the international community face [14]. 
It is a widely held view that the official publication of the 1987 Our Common Future Report by the World Commission on Environment and Development [10] has led to the integration of environmental protection policy. It has become "the leading concept in global environment management." As Biermann, Davies and van der Grijp point out, the authors of Brundtland's report emphasized that sustainable development "involves the environmental, economic and social dimension" [15].

It is indicated in the literature that environmental policy integration is part of the European legislation. The provisions of the Maastricht Treaty (1993) and the Amsterdam Treaty (1997) constitute its foundation [16].

Beunen, van der Knaap and Biesbroek define EPI as "a continuous process to ensure that environmental issues are included in all policy phases-policy negotiations, development, implementation and outcomes—and avoid situations where environmental degradation becomes subsidiary" [16].

Environmental policy integration is an element of sustainable development, which was established by the European Union member states in the procedure of wide consultations and arrangements. A consensus was reached, based on the conviction that the natural environment is a phenomenon and the protection of it should be the priority objective of all countries and societies. Nilsson and Persson citing A. Lenschow, emphasize that rationality and effectiveness are the starting point in the process of formulating the assumptions of environmental policy. What should be stressed, however, is the fact that some controversies still arise on different levels at the introductory stage [17]. The implementation of the EPI policy is a great challenge and there are numerous examples of how difficult this task is [18].

Lafferty and Hovden point out that EPI is one "of the key defining features of sustainable development" [19].

Ute Collier's definition of EPI is in turn based on three main objectives. First, she indicates that the implementation of the EPI concept should guarantee sustainable development and prevent damage to the environment. Second, its aim is to eliminate contradictions both between the existing policies and within their framework (boundaries). Third, the implementation of EPI should support current policies and ensure mutual benefits $[19,20]$.

As Kelemen notes, on the basis of the studies of DeSombre [21] and Falkner [22], there is no doubt that the "model of 'regulatory politics' explains the EU's leadership in international environmental politics, because it encompasses the effects of domestic politics and international regulatory competition." Environmental policies involve the necessity of adopting and implementing very strict regulations, which, consequently, may significantly limit member states' competitive capabilities on the international stage, at the same time as reducing their economic potential. European Union institutions face another important task, i.e., they need to work out agreements with other countries in the world regarding the adoption and implementation of such thorough and special regulations [23].

An important thing to note is that the EU's integration policy in the environmental aspect is created in a form that requires establishing a consensus concerning the adopted arrangements. As a result of seeking agreements and practical solutions by all entities involved in the decision-making process, the conditions are built to facilitate the accomplishment of the pre-determined goals [24].

It should be noted that, in the practical dimension, the EU's environmental policy focuses on issues such as water and air pollution and landscape degradation. Jordan and Jeppesen also emphasized that environmental problems arise from industry-related activities, including the energy and transportation sector, or agriculture [25].

What should also be stressed is the fact that the development of science and technology has led to the formulation of new regulations, e.g., the Environmental Technologies Action Plan (ETAP) [26], which serve the purpose of accomplishing the objectives of environmental policy [27].

Energy is indispensable for the functioning and survival of the whole world. As such, it is a constantly consumed resource that needs to be continually produced. Controlling energy production and management means to control a population that needs it. As a result of this, energy plays a pivotal role in power relations as a political resource. Studies on energy are advanced across all different scientific disciplines as energy production and allocation must be constantly rationalized [28-31]. 


\subsection{EU Policy on Renewable Energy Sources}

A particular type of energy is renewable energy, also known as clean energy, which "comes from natural sources or processes that are constantly replenished. For example, sunlight or wind keep shining and blowing, even if their availability depends on time and weather" [32]. It does not mean it is infinite, however, but significantly slows down the use of globally available amounts of resources and provides more time needed for finding new, more effective methods of energy production. As such, renewable energy resources have become a greatly important element of sustainable development [33]. The strategies of using renewable energy sources for sustainable development typically include "three major technological changes: energy savings on the demand side, efficiency improvements in the energy production, and replacement of fossil fuels by various sources of renewable energy" [34]. In consequence, comprehensive renewable energy implementation plans should involve coherent energy systems for which main indicators should be energy savings and efficiency measures. All in all, clean energy plays significant role in the policies of developed countries.

Renewable energy sources are also very important in the developmental processes of developing countries. Comprehensive studies in this area have been conducted by Barry, Steyn and Brent [35], who compared technologies of renewable energy in Rwanda, Tanzania and Malawi, and by Martinot and Reiche [36], who studied the cases of Argentina, Peru, Cape Verde, Bening/Togo, and Bolivia. All these authors found that using renewable energy technologies in developing countries results in these technologies becoming unsustainable. The main reason behind this is the insufficient infrastructure in terms of finance, technology, policy, environment and adoption by community [35]. This means that using clean energy for sustainable development requires a sustainable environment. Otherwise, they may be ineffective.

Interestingly, studies within social science have proven that adoption by community is a significant issue not only in developing countries. Stigka, Paravantis and Mihalakakou [37] claim that it is important "to know the attitudes of electricity consumers since their attitudes are the foundations of their resulting behaviour. Three specific parameters appear to underscore public behaviour: (a) information possessed by the public, (b) the public's perceptions and positions, and (c) fear, i.e., danger or anxiety that intensifies with ignorance". Other important factors identified by the authors are a "lack of information or knowledge on the new technologies, mistrust, lack of impartiality, and suspicion towards investors".

As mentioned, using renewable energy sources is of global importance. Therefore, it is a subject of geopolitical studies to scrutinize the role of clean energy in the processes of managing worldwide influence. A pivotal study in this area was conducted by O'Sullivan, Overland, and Sandalow [38], who focused particularly on mechanisms through which renewable energy sources can shape geopolitics. These include critical material supply chains, technology and finance, new resource curse, electric grids, reduced oil and gas demand, avoided climate change, and sustainable energy access. Especially important is the last mechanism, which creates a framework for dynamic relations between sustainable development, the use of renewable energy sources and geopolitics, in which the latter can be either the dependent or independent variable.

The newest evidence concerning the use of renewable energy sources indicate that it may be correlated with the type of political regime in a given country. Sequeira and Santos [39] demonstrate that democratic systems more than others favor clean energy to increase their range of influence. This was confirmed by Burke and Stephens [40], who had proven that "distributed energy-politics posits that distributed energy sources and technologies enable and organize distributed political power and vice versa". Interestingly, renewable energy systems therefore open the area for competition between political, economic and technological agendas, which, in democratic regimes, stimulates decentralization of power and internal energy markets.

Studies on renewable energy sources, technologies and systems are conducted in numerous areas including hard and social sciences. The most current directions concern the common implementation of clean energy technologies and increasing social awareness for the necessity of using them, rationalization of energy consumption and production, and developing responsible policies to make clean energy an element of strategies for sustainable development. 
A significant element of the European climate policy is the reduction in $\mathrm{CO}_{2}$ emissions into the atmosphere. One of the most efficient methods of reducing $\mathrm{CO}_{2}$ emissions is using renewable energy sources [41,42]. In searching for ways to improve the environmental order, renewable energy sources can also become a valuable export commodity, significantly impacting trade balances of particular countries $[43,44]$. RES also reduce the negative impact of economic growth on environmental degradation [45]. They can also become the so-called common resource used by regions or local communities [46], contributing to improving the standard of living of their inhabitants [47]. RES are particularly important in cities, which are the main culprit behind environmental pollution [48].

\subsection{Renewable Energy Implementation Policy in Poland}

An important element of Poland's environmental protection policy is adjusting the economy (the state, private and local government sectors) and the Polish people to the environmental standards set by the EU, and to the European climate and energy policy in particular [49]. Primarily, the directive on renewable energy sources is a key element of an energy system that will help to meet the EU task of achieving climate neutrality. The major pre-assumption of the European policy in this respect is decarbonization and reduction in greenhouse gasses emissions. The initial directive set out an overall policy on the production and promotion of RES energy [50], while the currently biding directive (2018) [7] is part of the "Clean Energy for All Europeans" package. Its major objective is Europe becoming the world leader in terms of renewable energy sources. EU member states are obliged to develop national integrated plans on energy and climate for 2021-2030 for achieving goals concerning RES energy. Each member state is obliged to implement the provisions of the new directive into their legislation by June 2021. Primarily, member states are required to allocate specific financial resources on supporting energy efficiency, with particular reference to poverty-stricken citizens. Another important task is securing citizens with the right to generate renewable energy for personal use, including storage and sale of potential output surplus.

The directive does not provide for sanctions in case of defaulting on its objectives. The consequences differ from state to state [51,52]. Member states are primarily obliged to report gradual implementation, showing a significant increase in the share of RES and its evenness. It is noteworthy to say that in 2020 Poland and a few other member states sent a letter to the European Commission on the new industrial strategy for Europe and applying RES to fight the consequences of COVID-19. The letter reads that "the ability to produce RES technologies could be of deciding importance in terms of EU's technology sovereignty beyond the COVID-19 pandemic" [53]. It should be noted that Poland is threatened with defaulting on meeting the obligations set for 2020.

The sustainable development of Poland is a constitutional provision and it is defined in the act on environmental protection as social-economic development that integrates political, economic and social activities while keeping environmental balance and preserving basic environmental processes for safeguarding the basic needs of particular communities or individuals of this and next generations [54].

In Poland, one of the prime documents on sustainable development is "The Strategy for Responsible Development until 2020 (with an Outlook to 2030)". It provides as follows: "Of particular importance will be activities aimed at enhancing the innovativeness of the energy sector, low emissions, intelligent grid development, construction of energy clusters, energy cooperatives, etc. The cooperation of R\&D and scientific centres with the energy sector in the area of developing and commercialising new technologies should be strengthened. Ultimately, innovating RES technologies should lead to the emergence of fully dispositional systems connected to the grid on market principles" [55]. It is further noted as follows: "One of the ways to reduce emissions in urban areas is through developing efficient low-emissions system heat-engineering and small local heating plants, applying cogeneration in heat production (particularly in local heating plants due to their emissions neutrality), standardisation of solid fuel propelled heat boilers and solid fuels used in individual heating and local heating plants. The changes in the media used in individual and housing heating should take into account the varied levels of economic and technology affordability of different groups of stakeholders (e.g., individual 
recipients, micro and small businesses) as well as the sustainability of the project. For the above reasons, the scope of assistance is of particular importance, including enhancement of the heating efficiency of buildings, replacement and upgrading of boilers for heat or heat and electricity production, the promotion and development of emissions neutral locally accessible sources of heat/cold (such as geothermal resources, biomass in energy production, etc.), the extension of heating networks, and the installation of filters reducing household emissions" [55].

Another important document on regulating the activities promoting sustainable development in Poland is "The National Agenda for Energy and Climate 2021-2030. Assumptions and Objectives; Policies and Activities" drawn up by the Ministry of State Assets. The agenda provides as follows: "In meeting the EU 2030 objective, Poland declares achieving 21-23\% share of RES in the final gross energy consumption by 2030 (total consumption in power engineering, heat and cold engineering, and transportation), while aiming at a reduction of $56-60 \%$ of coal share in electricity production. It is estimated that in the 2030 perspective the share of RES in heat and cold engineering will increase by $1.1 \%$ on annual average. As regards transportation the figure is $14 \%$. In order to facilitate achieving these objectives there are plans to support renewable energy sources through the continuation of the existing and development of new support and help mechanisms. Also assumed is increased consumption of advanced biofuels, the development of marine wind power, and enhancing the dynamics of the development of RES micro-installations" [56].

The most important document is "The Environmental Policy of the State 2030—A Development Strategy in the Area of the Environment and Water Management" signed by the Council of Ministers on 16 July 2020. The document is compliant with the act on the rules of pursuing the development policy. Its major task is to implement the guidelines for ensuring the environmental security of Poland and the high standard of living for all citizens. In the Polish system of strategic documents, the role of "The Environmental Policy of the State 2030" is to further specify other documents and make them fully operational, including the above-mentioned "Strategy for Responsible Development until 2020 (with an Outlook to 2030)". The document of 16 July 2020 reads as follows: "The environmental policy of the state will include providing support to local governments with regard to multi-management of area emissions (heating systems) and line emissions (transportation)" [57].

In keeping with the above-mentioned strategic documents, the state's policy on environmental order ought to focus on two areas, i.e., the improvement of the quality of the environment and preventive actions. The policy of environmental protection is to promote biodiversity. Environmental protection includes efforts aimed at improving the quality of air, water, soil and proper waste management.

In the state policy on improving the quality of the environment the following issues are of particular importance:

- Further reduction in the emission of carbon dioxide, sulfur, nitrogen and fine particulate matter in the production of energy in order to fully meet the obligations of the accession treaty and EU directives;

- $\quad$ Adopting solutions for energy saving and energy production from renewable energy sources in Poland's new energy policy by 2030;

- Taking due action in terms of preparing and implementing the technology on carbon capture and storage;

- Achieving or maintaining satisfactory condition of water by finalizing the program of construction and extension of sewage treatment plants and sewage systems in urban areas under the EU Operational Programme: Infrastructure and Environment;

- Developing plans on water management for each river basin;

- Devising the national water and environment program;

- Reducing pollution caused by dangerous substances of industrial origin;

- Increasing energy recovery from communal waste;

- Increasing the amount of recovered waste produced in households by over $50 \%$; 
- Devising an efficient mechanism of control over chemical substances officially available on the market;

- Removal of biphenyl chloride from transformers and other appliances;

- Removal of asbestos.

- As regards preventive actions, the top priorities include as follows:

- Monitoring the contamination of air, water and soil with control and measurement tests;

- Informing the decision-makers and the public on contamination, and giving alerts in case of particular emergency;

- Damage liquidation through rescue and recovery operations;

- Preventive and educational efforts with regard to dangerous substances;

- Efforts aimed at restoring the environment's natural condition [58].

A significant element for improving environmental order will be the proceedings in the energy sector, primarily meeting the requirements of environmental protection, including more extensive use of renewable energy sources.

The activities involving the implementation of environmental order across provinces are taking place at a number of levels, i.e., government investments and projects of local governments at different levels. Within the latter, provincial local governments pursue specific development policies, which include rational exploitation of natural resources and exploiting the environment in accordance with the sustainable development principle [59]. Under the act on environmental protection, the tasks of the province marshal include all matters relating to the fees for using the environment, particularly gas or fine matter emissions, discharge of sewage into water or soil, water intake, and waste storage. Furthermore, the tasks of the province marshal in the area of environmental protection also include:

- Development, implementation and monitoring of provincial programs on environmental protection;

- Controlling and evaluating the condition of the environment in the region;

- Developing programs on air protection with a view to achieving maximum acceptable levels of substances in the air.

Local governments at all levels implement a great number of tasks relating to environmental order. They cooperate with state services and institutions and non-governmental organizations. In Poland, financial resources for environmental governance activities, including one of its most important elements, i.e., RES, come from a number of sources:

- EU funds (the Cohesion Fund, the EU Fund: Infrastructure and Environment);

- Direct investments from particular ministries' resources (primarily, the ministries involved in environmental issues, i.e., the ministry of economy, the ministry of transport, the ministry of energy, the ministry of agriculture and rural development);

- Local governments' own resources (communal, county and provincial funds for environmental protection);

- Resources allocated centrally through relevant agencies (primarily, the National Fund for Environmental Protection and Water Management, e.g., the program aimed at local governments "Clean Air", and to a certain degree the National Water Holding "Polish Water").

In 2018, the total amount of Poland's investment in fixed assets in environmental protection was PLN 10.4 b (6.8 b in 2017), while investment in fixed assets in water management came to ca. PLN 2.5 $\mathrm{b}(2.1 \mathrm{~b}$ in 2017). In 2018, investment in environmental protection and water management accounted for $0.49 \%$ and $0.12 \%$ GDP, respectively $(0.34 \%$ and $0.10 \%$ in 2017 , respectively). The main investors in fixed assets in environmental protection in Poland are enterprises, followed by the basic units of local government, i.e., communes, followed by central budget units [60].

In 2018, the investment in fixed assets in environmental protection in Poland mostly included investments in sewage management and water protection as well as air and climate protection, with 
a share of $52.3 \%$ and $28.3 \%$, respectively. The remaining $19.4 \%$ investment consists of investments in waste management $(6.9 \%)$, bio-diversity and landscape conservation $(1.4 \%)$, noise and vibrations reduction $(1.0 \%)$, soil and underground/surface water conservation $(0.5 \%)$, research and development $(0.1 \%)$, and other activities relating to environmental protection $(9.6 \%)$. In 2018, investment in fixed assets in sewage management and water protection was PLN $5.4 \mathrm{~b}$. The biggest investments in this respect were made by the following provinces: Masovian (14.7\%), Greater Poland (12.3\%) and Silesian $(9.8 \%)$. The smallest investments were made by: Warmian-Masurian (2.2\%), Lubusz (2.3\%) and Opole $(2.7 \%)[60]$.

\section{Materials and Methods}

The assessment of environmental order under the methodology of the main statistical office (pursuant with international methodology [61]) is made up of seven groups of indicators including climate change, energy, air conservation, fresh water conservation, land management, bio-diversity, waste management. They include seventeen different types of indicators for tracking the advances of territorial units (the whole country or its parts) in implementing the concept of sustainable development (cf. Table 1).

Table 1. Sustainable development indicators in the area of environmental order.

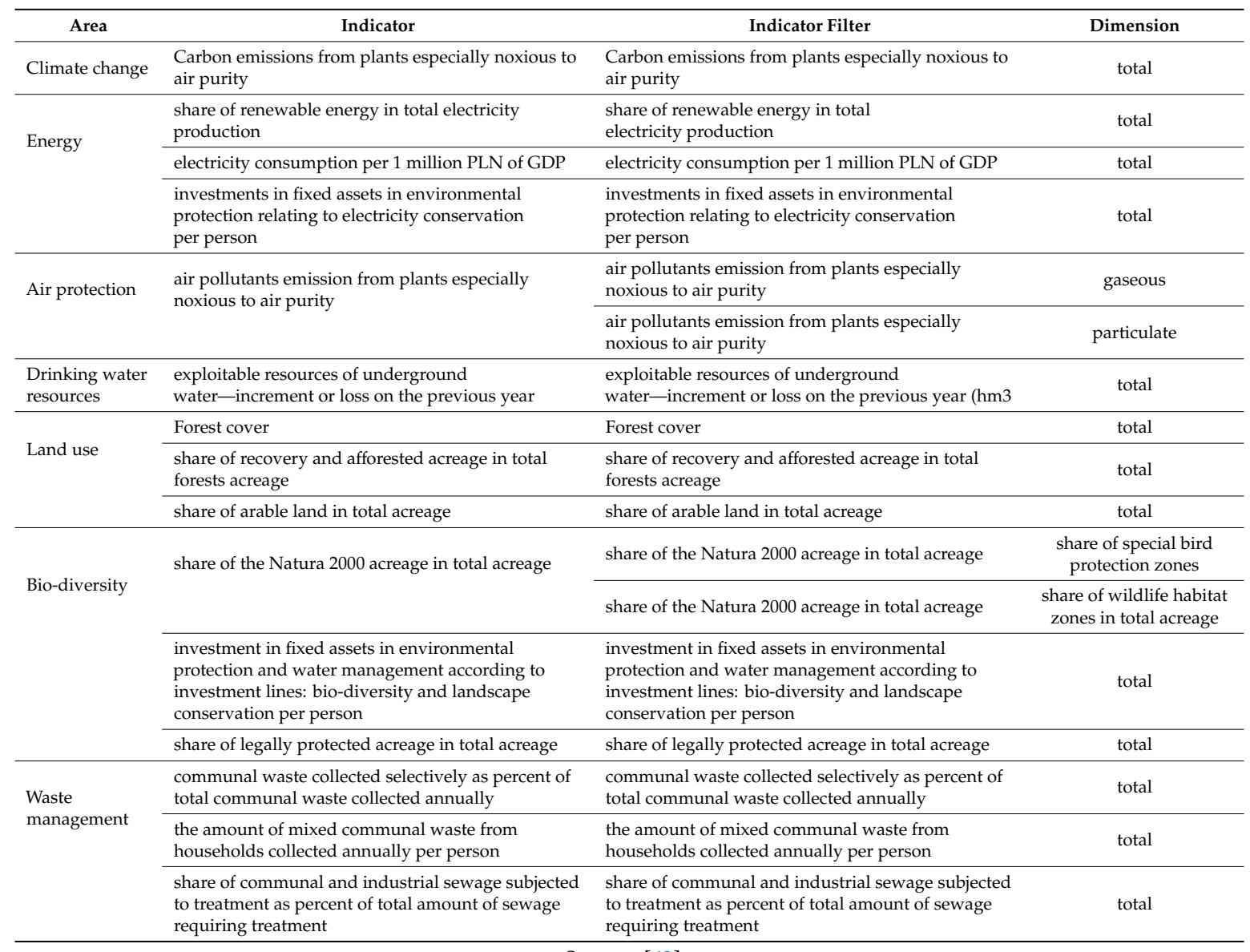

Source: [62].

This study deals with the taxonomic assessment of local sustainable development in Poland's major administration units, i.e., provinces, in the area of environmental order. To this end, the methods of linear ordering were applied for the assessment of the level of objects differentiation with the use of a closed set of statistical features [63-66]. The applied method is also described in detail by other authors [44,67-70]. 
It should be noted that the list of indicators used in the construction of the synthetic measure of provinces' sustainable development in the area of environmental order is limited due to the guidelines and hence the resources of national statistics. Consequently, this research fails to take into account any features other than those of the main statistical office (cf. Table 1). Therefore, the process of variables selection (the first phase in constructing the synthetic measure) is limited. In this research, a decision was made not to assign significance to particular diagnostic variables.

The next phase in constructing the synthetic measure is features standardization. This can be performed in a number of ways. The selection of the features standardization method depends on the method of establishing the synthetic measure. Basically, "the procedures for establishing the synthetic measure can be divided into two major groups:

- non-benchmark methods,

- benchmark methods" [71].

In this study, the benchmark method was applied, assuming the existence of the so-called model object, against which the taxonomic distances of the objects under examination are determined. "In practical research, the typical and most often applied synthetic variable of this methods group is the Hellwig measure (due to its original application in examining economic growth also called the growth measure)" [71].

In the event of applying the Hellwig measure, features standardization is performed with the following Equation:

$$
x_{i j}=\frac{x_{i j}-\bar{x} j}{S_{j}}
$$

where:

$x_{i j}$-empirical values of $j$ th feature in ith object.

$\bar{x} j$-the arithmetic mean of $j$ th feature.

$S_{j}$-standard deviation of $j$ th feature.

Establishing the benchmark consists of selecting from standardized matrixes with the above featured equation, the maximum value for stimulants and possibly the minimum value for the features other than stimulants

$$
x_{0 k}=\left\{\begin{array}{l}
\max _{i} x_{i j} \text { dla } j \in S \\
\min _{i} x_{i j} \text { dla } j \notin S
\end{array} .\right.
$$

The synthetic measure is:

$$
d_{i}=1-\frac{d_{i 0}}{d_{0}}
$$

where:

$d_{i 0}$ - the Euclidean distance of object $x_{i}$ from benchmark object $x_{0}$.

$d_{0}$ - the critical distance of particular unit from the benchmark.

The Euclidean distance is calculated with the following equation:

$$
d_{i 0}=\sqrt{\sum_{j=1}^{p}\left(x_{i j}-x_{0 j}\right)^{2}}
$$

while the critical distance of particular unit from the benchmark is calculated with:

$$
d_{0}=\bar{d}_{0}+2 s_{d}
$$

where: 
$\bar{d}_{0}$-the arithmetic mean of taxonomic distances:

$$
\bar{d}_{0}=\frac{\sum_{i=1}^{n} d_{i 0}}{n}
$$

$s_{d}$-standard deviation of taxonomic distances:

$$
s_{d}=\sqrt{\frac{\sum_{i=1}^{n}\left(d_{i 0}-\bar{d}_{0}\right)^{2}}{n}} .
$$

In order to carry out a taxonomic examination into the advances of provinces in implementing the assumptions of sustainable development in the area of environmental order, seventeen object (province) features were selected:

$\mathrm{X}_{1 \mathrm{t}}$-carbon emissions from plants especially noxious to air purity (tons per year).

$\mathrm{X}_{2 \mathrm{t}}$-share of renewable energy in total electricity production (\%).

$\mathrm{X}_{3 \mathrm{t}}$-electricity consumption per PLN one million GDP (GWh).

$\mathrm{X}_{4 \mathrm{t}}$-investments in fixed assets in environmental protection relating to electricity conservation per person (Polish zloty).

$\mathrm{X}_{5 \mathrm{t}}$-air pollutants emission from plants especially noxious to air purity-gas (tones per year).

$\mathrm{X}_{6 \mathrm{t}}$-air pollutants emission from plants especially noxious to air purity-particulate matter (tones per year).

$\mathrm{X}_{7 \mathrm{t}}$-exploitable resources of underground water-increment or loss on the previous year ( $\left.\mathrm{hm} 3\right)$.

$\mathrm{X}_{8 \mathrm{t}}$-forest cover.

$\mathrm{X}_{9 \mathrm{t}}$-share of recovery and afforested acreage in total forests acreage.

$\mathrm{X}_{10 \mathrm{t}}$ - share of arable land in total acreage.

$X_{11 t}$-share of the Natura 2000 acreage in total acreage-share of special bird protection zones.

$\mathrm{X}_{12 \mathrm{t}}$-share of the Natura 2000 acreage in total acreage-share of wildlife habitat zones in total acreage.

$\mathrm{X}_{13 \mathrm{t}}$-investment in fixed assets in environmental protection and water management according to investment lines: bio-diversity and landscape conservation per person (Polish zloty).

$\mathrm{X}_{14 \mathrm{t}}$-share of legally protected acreage in total acreage.

$\mathrm{X}_{15 \mathrm{t}}$-communal waste collected selectively as percent of total communal waste collected annually.

$\mathrm{X}_{16 \mathrm{t}}$-the amount of mixed communal waste from households collected annually per person $(\mathrm{kg})$.

$\mathrm{X}_{17 \mathrm{t}}$-share of communal and industrial sewage subjected to treatment as percent of total amount of sewage requiring treatment.

The selection of features for the construction of the synthetic measure had to be performed very carefully. First, the data reflecting the condition of particular features ought to be complete. Second, data should be collected under the same methodology. Third, features must not be excessively correlated with one another.

Pearson's correlation table (cf. Table 2) shows that some of the indicators are strongly correlated, which means they behave similar to other variables. It is a natural phenomenon within the area under discussion, for many areas of sustainable development remain strongly correlated. Examples of the most strongly correlated features include carbon emissions from particularly oppressive plants (X1), which behave similar to emissions of air pollutants from particularly oppressive plants (X5), or electricity consumption per one million PLN of GDP, and also features X11 and X12, which are vehicles of similar information. The strongest negative correlation was reported in the case of forest cover and farmland cover (X8 and $\mathrm{X} 10)$, which is quite natural as the bigger area of forests means the smaller area of farmland, and vice versa. In this case, the selection of data is limited by the availability of statistical data. Due to the above, subsequent stages of the research excluded the features of the most strongly correlated pairs, i.e., X5 and X10. 
Table 2. Pearson's table featuring correlations between selected indicators.

\begin{tabular}{|c|c|c|c|c|c|c|c|c|c|c|c|c|c|c|c|c|c|}
\hline $\mathrm{X} 1$ & 1 & & & & & & & & & & & & & & & & \\
\hline $\mathrm{X} 1$ & -0.61 & & & & & & & & & & & & & & & & \\
\hline $\mathrm{X} 1$ & 0.76 & -0.56 & & & & & & & & & & & & & & & \\
\hline $\mathrm{X} 1$ & 0.28 & -0.33 & 0.03 & & & & & & & & & & & & & & \\
\hline $\mathrm{X} 1$ & 1.00 & -0.61 & 0.76 & 0.29 & & & & & & & & & & & & & \\
\hline X1 & 0.67 & -0.43 & 0.76 & 0.44 & 0.68 & & & & & & & & & & & & \\
\hline $\mathrm{X} 1$ & 0.35 & -0.06 & 0.34 & -0.09 & 0.35 & 0.11 & & & & & & & & & & & \\
\hline $\mathrm{X} 1$ & -0.48 & 0.20 & -0.34 & -0.03 & -0.48 & -0.15 & -0.61 & & & & & & & & & & \\
\hline $\mathrm{X} 1$ & -0.26 & 0.21 & -0.30 & 0.27 & -0.25 & 0.07 & -0.66 & 0.69 & & & & & & & & & \\
\hline $\mathrm{X} 1$ & 0.39 & -0.27 & 0.19 & 0.04 & 0.38 & -0.05 & 0.57 & -0.95 & -0.66 & & & & & & & & \\
\hline $\mathrm{X} 1$ & -0.66 & 0.65 & -0.41 & -0.60 & -0.66 & -0.41 & -0.29 & 0.58 & 0.30 & -0.55 & & & & & & & \\
\hline $\mathrm{X} 1$ & -0.56 & 0.39 & -0.41 & -0.22 & -0.56 & -0.30 & -0.54 & 0.54 & 0.55 & -0.46 & 0.75 & & & & & & \\
\hline $\mathrm{X} 1$ & 0.15 & -0.19 & 0.21 & 0.54 & 0.16 & 0.40 & 0.06 & 0.21 & 0.21 & -0.23 & -0.18 & 0.05 & & & & & \\
\hline $\mathrm{X} 1$ & -0.29 & 0.37 & -0.01 & -0.60 & -0.29 & -0.35 & 0.14 & -0.07 & -0.04 & 0.10 & 0.31 & 0.08 & -0.44 & & & & \\
\hline $\mathrm{X} 1$ & 0.50 & -0.54 & 0.43 & 0.65 & 0.51 & 0.63 & 0.14 & -0.34 & -0.18 & 0.27 & -0.62 & -0.45 & 0.17 & -0.52 & & & \\
\hline $\mathrm{X} 1$ & 0.02 & 0.05 & 0.21 & -0.43 & 0.02 & 0.04 & -0.08 & 0.32 & -0.02 & -0.45 & 0.23 & 0.00 & 0.17 & -0.08 & -0.45 & & \\
\hline $\mathrm{X} 1$ & -0.41 & 0.28 & -0.32 & -0.61 & -0.42 & -0.60 & 0.20 & 0.09 & -0.41 & -0.01 & 0.49 & 0.09 & -0.18 & 0.05 & -0.37 & 0.35 & \\
\hline \multirow[t]{2}{*}{$\mathrm{X} 1$} & 0.05 & -0.06 & 0.08 & -0.03 & -0.05 & -0.06 & -0.11 & 0.12 & -0.03 & -0.19 & 0.16 & -0.04 & -0.07 & -0.18 & -0.41 & 0.35 & 1 \\
\hline & $\mathrm{X} 1$ & $\mathrm{X} 2$ & X3 & X4 & X5 & X6 & X7 & X8 & X9 & $\mathrm{X} 10$ & X11 & X12 & $\mathrm{X} 13$ & X14 & X15 & X16 & X17 \\
\hline
\end{tabular}

Amongst the features meeting the above listed requirements, the following features were recognized as stimulants: $X_{2 t}, X_{4 t}, X_{7 t}, X_{8 t}, X_{9 t}, X_{11 t}, X_{12 t}, X_{13 t}, X_{14 t}, X_{15 t}$, and $X_{17 t}$, while all the other as destimulants.

Considering that some features are recognized as stimulants while some others are recognized as destimulants, it is worth pointing to significant ranking discrepancies between particular provinces with regard to the features under examination. For instance, as regards carbon emissions from particularly oppressive plants, the Lubusz province takes the second last place. However, as the feature is a destimulant, it is a very good result. However, as regards the amount of mixed communal waste from households collected annually per person, the Lubusz province takes the third place. Taking into account the fact that the more mixed communal waste per person the worse result, third place in the ranking is a bad result.

The same applies to other features and other provinces. Such discrepancies make an overall and objective assessment of the advances of provinces in implementing the objectives of sustainable development in the area of environmental order possible only by applying the synthetic measure.

\section{Results and Discussion}

The results of the taxonomic analysis presented in Figure $1 \mathrm{imply} \mathrm{a} \mathrm{number} \mathrm{of} \mathrm{important} \mathrm{conclusions.}$ First, the obtained volumes of the synthetic measure are relatively small. Second, the taxonomic distances between most of the synthetic measures for particular provinces are relatively large. Third, some provinces made significant progress in developing environmental order during the years under examination. Fourth, there are provinces that reported a drop in the value of the integrated measure.

In 2016, the mean value of the taxonomic measure was 0.171437741 and 14 out of 16 units (provinces) obtained measures within the range from 0.1 to 0.25 . This implies relatively small differences between these provinces in achieving the objectives of sustainable development in the area of environmental order. Furthermore, 2018 saw relatively significant changes in the ranking and the volume of the synthetic measure itself. Particularly big progress was made by the Podlaskie province, whose taxonomic synthetic measure in the area of environmental order was over 0.41 . It is not a particularly high value, but it does stand out compared to the other provinces. The Podlaskie province stands out in a number of areas taken into account when constructing the synthetic measure. For instance, the province reports the lowest consumption of electricity per PLN one million of GDP, the biggest share of wildlife habitat zones in total acreage, and high ranking positions in a number of other areas (main statistical office). 


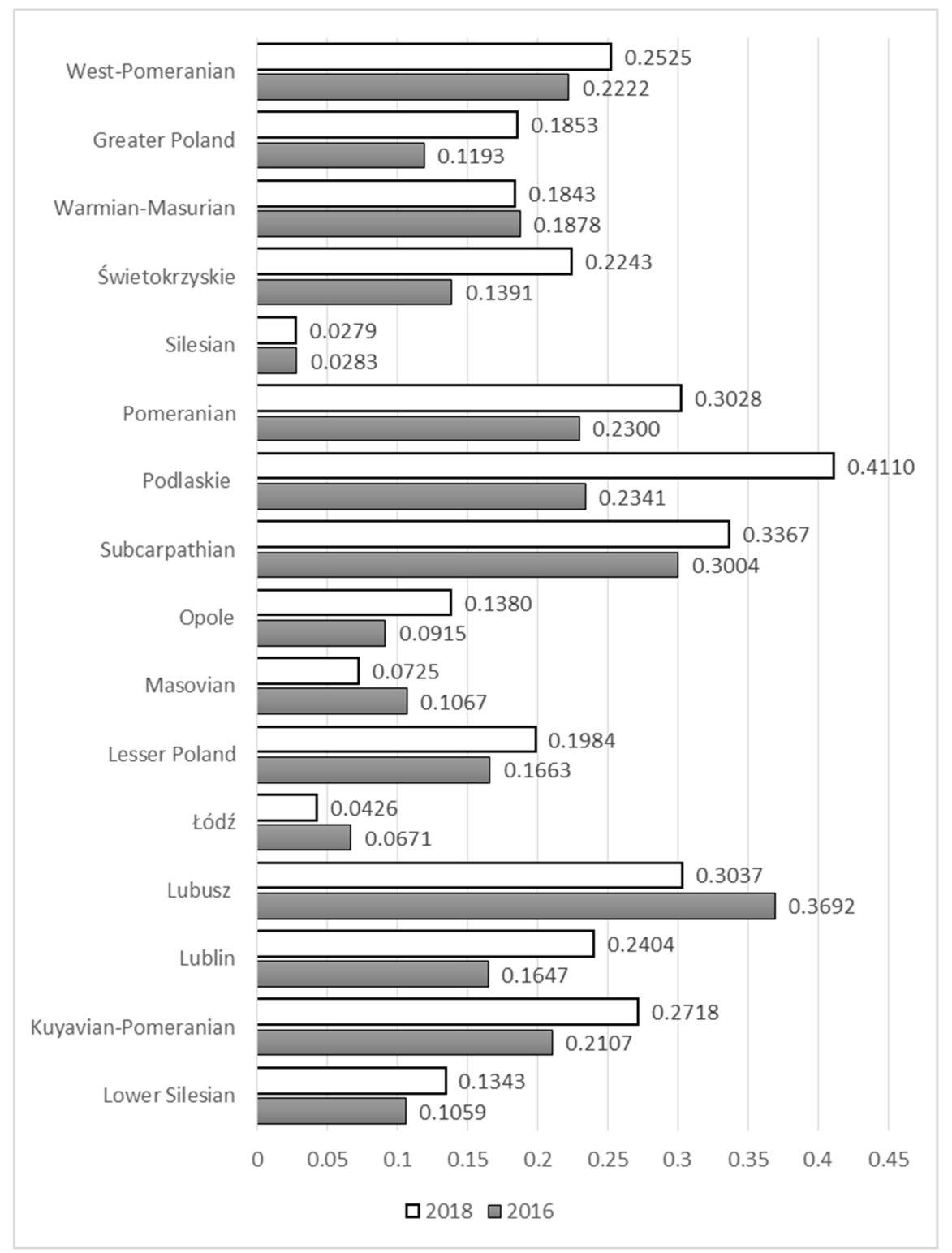

Figure 1. The taxonomic measure of local sustainable development (in the area of environmental order) of Polish provinces (2016 and 2018).

The provinces that fare much worse in the area under assessment are the Łódź province and the Silesian province. They both reported the lowest values of the synthetic measure in the two years under examination, i.e., below 0.07 (cf. Figure 1). The position of the capital province-Masovian-is of interest too, as it achieved one of the weakest results in both years under consideration. Despite the fact that the most developed Polish agglomeration is located in the province, it failed to take a high place in the ranking. One of the reasons is that the province is one of the most densely populated regions of the country. Many of the indicators used in the research are provided on a per capita basis. This is why they often achieved low values. It is also worth taking note of the discussion going on in Poland regarding separating the Warsaw agglomeration from the Masovian province. In many respects, e.g., EU funds allocation, such a solution would turn out particularly beneficial to the non-agglomeration part of the province [72].

Table 3 shows significant changes in the ranking of provinces over the two years under examination. As many as 11 provinces changed their ranking positions, with six going up and five going down the table. The following provinces improved their positions by two places: Lublin, Opole, Podlaskie 
and Świętokrzyskie. The Warmian-Masurian province reported the biggest drop (four places down the table), even though the integrated development measure did not change considerably (only a slight drop).

Table 3. Ranking of provinces based on the integrated measure of sustainable development in the area of environmental order in the years 2016 and 2018.

\begin{tabular}{cccccc}
\hline \multirow{2}{*}{ Provinces } & \multicolumn{2}{c}{ 2016 } & \multicolumn{2}{c}{ 2018 } & \multirow{2}{*}{ 2018-2016 } \\
\cline { 2 - 5 } & $\begin{array}{c}\text { Development } \\
\text { Measure }\end{array}$ & $\begin{array}{c}\text { Ranking } \\
\text { Position }\end{array}$ & $\begin{array}{c}\text { Development } \\
\text { Measure }\end{array}$ & $\begin{array}{c}\text { Ranking } \\
\text { Position }\end{array}$ & \\
\hline Lower Silesian & 0.105851953 & 13 & 0.134297781 & 13 & 0 \\
Kuyavian-Pomeranian & 0.210717745 & 6 & 0.271798249 & 5 & 1 \\
Lublin & 0.164650728 & 9 & 0.240409693 & 7 & 2 \\
Lubusz & 0.369194098 & 1 & 0.303676766 & 3 & -2 \\
Łódź & 0.067062895 & 15 & 0.042582929 & 15 & 0 \\
Lesser Poland & 0.16625483 & 8 & 0.198365692 & 9 & -1 \\
Masovian & 0.106749877 & 12 & 0.072532522 & 14 & -2 \\
Opole & 0.091456056 & 14 & 0.138016699 & 12 & 2 \\
Subcarpathian & 0.300367945 & 2 & 0.336721173 & 2 & 0 \\
Podlaskie & 0.234082885 & 3 & 0.410961473 & 1 & 2 \\
Pomeranian & 0.229962032 & 4 & 0.302797901 & 4 & 0 \\
Silesian & 0.028313756 & 16 & 0.027945084 & 16 & 0 \\
Swiętokrzyskie & 0.139084245 & 10 & 0.22432936 & 8 & 2 \\
Warmian-Masurian & 0.187809831 & 7 & 0.184300111 & 11 & -4 \\
Greater Poland & 0.11929203 & 11 & 0.185303006 & 10 & 1 \\
West Pomeranian & 0.222152952 & 5 & 0.252491807 & 6 & -1 \\
\hline
\end{tabular}

The synthetic indicator under analysis not only allows sorting the objects (provinces) in order, but also distinguishing groups of similar objects. Cluster analysis allows the distinguishing of groups of similar objects (provinces) on the condition that they are described by more than one feature [73]. Thus, four groups of provinces were distinguished, and based on the synthetic indicator $(0: 1)$, the groups share the same distribution, i.e., 0.25 .

Table 4. Comparison of the level of sustainable development of Polish provinces according to the taxonomic measure in the area of environmental order (2016).

\begin{tabular}{|c|c|c|c|}
\hline \multicolumn{4}{|c|}{ The Level of Sustainable Development in the Area of Environmental Order: } \\
\hline $\begin{array}{l}\text { Very High } \\
\text { TMD } \geq 0.75 \\
\text { (A) }\end{array}$ & $\begin{array}{c}\text { High } \\
0.5 \leq \text { TMD }<0.75 \\
\text { (B) }\end{array}$ & $\begin{array}{c}\text { Medium } \\
0.5>\text { TMD } \geq 0.25 \\
\text { (C) }\end{array}$ & $\begin{array}{c}\text { Low } \\
\text { TMD }<0.25 \\
\text { (D) }\end{array}$ \\
\hline & & $\begin{array}{c}\text { Lubusz } \\
\text { Subcarpathian }\end{array}$ & $\begin{array}{c}\text { Warmian-Masurian } \\
\text { Lower Silesian } \\
\text { Kuyavian-Pomeranian } \\
\text { Greater Poland } \\
\text { Świętokrzyskie } \\
\text { Opole } \\
\text { Silesian } \\
\text { Łódź } \\
\text { Masovian } \\
\text { Lubusz } \\
\text { Lesser Poland } \\
\text { West Pomeranian } \\
\text { Podlaskie } \\
\text { Pomeranian }\end{array}$ \\
\hline
\end{tabular}

The abovementioned low value of the synthetic measure results in almost all provinces being in the group D. This translates into their level of sustainable development in the area of environmental order being low. Only two provinces entered the third group C. They were the Lubusz province and the Subcarpathian province (cf. Table 4). This means that according to the level of the synthetic 
measure, sustainable development in the area of environmental order can be regarded as medium at most. Notably, not a single province managed to enter groups A and B. This means a relatively low level of sustainable development of Polish provinces in the area of environmental order in 2016.

The situation changed slightly in 2018. The mean value of the taxonomic measure across provinces was 0.20790814 , which is an increase of over $21 \%$. Another four provinces managed to enter the third group of clusters (group C), namely the Kuyavian-Pomeranian province, the Podlaskie province, the Pomeranian province and the West Pomeranian province (cf. Table 5).

Table 5. Comparison of the level of sustainable development of Polish provinces according to the taxonomic measure in the area of environmental order (2018).

\begin{tabular}{cccc}
\hline \multicolumn{4}{c}{ The Level of Sustainable Development in the Area of Environmental Order: } \\
\hline $\begin{array}{ccc}\text { Very High } \\
\text { TMD } \geq \mathbf{0 . 7 5}\end{array}$ & High & Medium & Low \\
(A) & $\mathbf{0 . 5} \leq$ TMD $<0.75$ & $\mathbf{0 . 5}>$ TMD $\geq \mathbf{0 . 2 5}$ & TMD $<\mathbf{0 . 2 5}$ \\
(B) & (C) & (D) \\
\hline & Podlaskie & Warmian-Masurian \\
& Subcarpathian & Lower Silesian \\
& Kuyavian-Pomeranian & Greater Poland \\
& Lubusz & Swiètokrzyskie \\
& Pomeranian & Opole \\
& West Pomeranian & Silesian \\
& & Łódź \\
& & Masovian \\
& & Lesser Poland \\
& & Podlaskie \\
& & Lublin \\
\hline
\end{tabular}

However, it is true that not a single province made it into the first and second group of clusters of the synthetic measure (groups A and B). This means that the level of sustainable development of Polish provinces in the area of environmental order remains relatively low.

The key issue considered in this study is the influence of RES financing on the integrated measure of sustainable development in the area of environmental order. Table 6 presents the nominal and relative changes of the taxonomic measure of sustainable development in the area of environmental order (cf. Figure 1) after removing the financing of RES by provincial local governments from the list of indicators.

Table 6. Changes in the taxonomic measure of sustainable development following the removal of RES financing from the list of indicators (2016 and 2018).

\begin{tabular}{ccccc}
\hline & \multicolumn{2}{c}{$\mathbf{2 0 1 6}$} & \multicolumn{2}{c}{$\mathbf{2 0 1 8}$} \\
\cline { 2 - 5 } & $\begin{array}{c}\text { TMD Nominal } \\
\text { Change }\end{array}$ & TMD Change (\%) & $\begin{array}{c}\text { TMD Nominal } \\
\text { Change }\end{array}$ & TMD Change (\%) \\
\hline Lower Silesian & 0.024085 & $22.75 \%$ & 0.020036 & $14.92 \%$ \\
Kuyavian-Pomeranian & 0.012942 & $6.14 \%$ & 0.006943 & $2.55 \%$ \\
Lublin & 0.039056 & $23.72 \%$ & 0.000408 & $0.17 \%$ \\
Lubusz & -0.02336 & $-6.33 \%$ & 0.003161 & $1.04 \%$ \\
Łódź & -0.04055 & $-60.47 \%$ & -0.04599 & $-108.00 \%$ \\
Lesser Poland & 0.008213 & $4.94 \%$ & 0.018812 & $9.48 \%$ \\
Masovian & 0.005021 & $4.70 \%$ & 0.019181 & $26.45 \%$ \\
Opole & -0.00095 & $-1.04 \%$ & -0.00586 & $-4.25 \%$ \\
Subcarpathian & 0.048728 & $16.22 \%$ & 0.061079 & $18.14 \%$ \\
Podlaskie & 0.002462 & $1.05 \%$ & 0.024361 & $5.93 \%$ \\
Pomeranian & 0.051216 & $22.27 \%$ & 0.020309 & $6.71 \%$ \\
Silesian & 0.00272 & $9.61 \%$ & 0.046159 & $165.18 \%$ \\
Swiętokrzyskie & 0.011112 & $7.99 \%$ & -0.01243 & $-5.54 \%$ \\
Warmian-Masurian & 0.045844 & $24.41 \%$ & 0.053305 & $28.92 \%$ \\
Greater Poland & 0.04369 & $36.62 \%$ & 0.045946 & $24.80 \%$ \\
West Pomeranian & 0.011562 & $5.20 \%$ & 0.045951 & $18.20 \%$ \\
median & 0.015111 & 0.073628 & 0.018836 & $12.79 \%$ \\
\hline
\end{tabular}


As a result of such a treatment, some remarkably interesting results were obtained. The elimination of the integrated measure of RES financing provided truly surprising results in the two years under examination. In 2016, following the removal of RES financing, the mean taxonomic measure for all provinces grew by more than $7 \%$. An increase in the taxonomic measure of sustainable development in the area of environmental order after the removal of RES financing means that the financing is insufficient and does not impact the total value of the indicator negatively. In 2016, the only three provinces that experienced a drop in the measure following the treatment was the Łódzkie province $(-60.5 \%)$, the Lubusz province $(-6.3 \%)$ and the Opole province $(-1 \%)$. This implies that in these provinces RES financing exerts a positive influence on the value of the integrated measure of sustainable development in the area of environmental order.

Performing a similar treatment in 2018 gave somewhat different results. Primarily, the mean change in the integrated measure is $12.8 \%$. This implies that, on average, in 2018 RES financing had less influence on the integrated measure than in 2016. Obviously, the changes vary across particular provinces. The biggest impact on the mean value was exerted by the Silesian province (165\%). However, another three provinces also reported drops in the integrated measure values (the Łódź province, the Opole province and the Świętokrzyskie province). This means that in those provinces RES financing exerts positive impact on the integrated measure value. Following the removal of RES financing from the integrated measure, all of the other provinces reported an increase in the measure value.

\section{Conclusions}

In conclusion, it must be stated that the synthetic measure is better suited to reflect the changes in the progress in implementing the objective of sustainable development in the area of environmental order than the observation of single indicators. In the plan of many international organizations and institutions (e.g., the UN, the European Commission), the pressure on implementing the objectives of sustainable development is to urge countries worldwide to perform comprehensive monitoring of the processes ongoing in their economies. This means that in some areas progress is faster while in some other areas it is slower, with regress in some other areas. The advantage of the synthetic measure is the comprehensive outlook on the whole problem. Including all advances in meeting the goals of sustainable development in the area of environmental order in a single measure allows carrying out a simple comparison of their implementation in a large number of administration units. On the other hand, changes caused by the movements within one of the component measures of the synthetic measure result in relatively small changes in the overall measure.

The results of the study confirm the assumption of hypothesis 1 -the engagement of the provinces under examination in implementing the tasks of sustainable development vary greatly. The taxonomic distances between synthetic measures for particular provinces are considerable. The highest values of the integrated measure in 2018 were achieved by the following provinces: Podlaskie, Subcarpathian and Lubusz. It is worth noting some major changes in the ranking between 2018 and 2016. In 2018, the 2016 ranking leader-Lubusz-dropped to the third place. The difference in the value of the integrated development measure between the highest and lowest ranking provinces (Podlaskie and Silesian, respectively) came to almost 0.4 , which signifies considerable differences between particular regions in terms of their level of sustainable development. Cluster analysis findings allow the grouping of the objects (provinces) in the lower distribution quartiles of the synthetic measure. This signifies low and very low levels of sustainable development in the area of environmental order. However, the cluster analysis showed some progress in achieving the goals of sustainable development. In 2018, group C (median) included six provinces compared to two provinces in 2016.

The procedure of removing RES financing by provinces from the integrated measure reveals that the financing is insufficient. In most cases, it fails to exert a positive impact on the measure under discussion. However, it should also be noted that the overall situation improved between 2016 and 2018. The removal of a single indicator, i.e., the financing of RES, from the integrated measure led to an average growth in the integrated measure in both the years under consideration. Following this 
operation, only three provinces reported their nominal drop in 2016, i.e., Lubusz, Łódź and Opole. In 2018, a drop in the nominal value of the integrated measure was also reported by three provinces (Łódź, Opole, Świętokrzyskie). This implies that, on average, the financing of renewable energy sources exerts increasingly smaller impact on the level of sustainable development in Poland.

In conclusion, it is worth stressing that the method applied in the research features certain limitations. Primarily, it was decided not to give weight to particular indicators. This means that each of them influences the value of the integrated measure to a similar extent. In reality, in some regions certain variables exert bigger impact on the level of sustainable development, while in some other regions the impact is lesser. Thus, giving the same weight to the whole country could be an incorrect procedure. Some other types of limitations result from statistical assumptions. In the classical statistical analysis, it is possible, for instance, to compute the level of significance or the determination coefficient. However, the above presented approach does not cover these type of issues [11].

Author Contributions: Conceptualization, P.S., and P.T.; methodology, P.S. and P.T.; software, J.G.; formal analysis, P.S., P.T. and J.M.-K.; investigation, P.S.; data curation, P.S.; writing-original draft preparation, P.S., P.T., and J.M.-K.; writing - review and editing, P.S., P.T., J.M.-K. and J.G.; supervision, P.S.; validation, P.S., P.T., J.M.-K. and J.G.; funding acquisition, J.G. All authors have read and agreed to the published version of the manuscript.

Funding: This research received no external funding.

Conflicts of Interest: The authors declare no conflict of interest.

\section{References}

1. Li, H.; Song, W. Characteristics of Climate Change in the Lancang-Mekong Sub-Region. Climate 2020, 8, 115. [CrossRef]

2. Loh, P.S.; Alnoor, H.I.M.; He, S. Impact of Climate Change on Vegetation Cover at South Port Sudan Area. Climate 2020, 8, 114. [CrossRef]

3. Zeng, F.; Ma, M.-G.; Di, D.-R.; Shi, W.-Y. Separating the Impacts of Climate Change and Human Activities on Runoff: A Review of Method and Application. Water 2020, 12, 2201. [CrossRef]

4. Dovì, V.G.; Battaglini, A. Energy Policy and Climate Change: A Multidisciplinary Approach to a Global Problem. Energies 2015, 8, 13473-13480. [CrossRef]

5. Kung, C.-C.; McCarl, B.A. Sustainable Energy Development under Climate Change. Sustainability 2018, 10, 3269. [CrossRef]

6. Ma, J.; Oppong, A.; Acheampong, K.N.; Abruquah, L.A. Forecasting Renewable Energy Consumption under Zero Assumptions. Sustainability 2018, 10, 576. [CrossRef]

7. European Parliament. European Commission Directive (EU) 2018/2001 of the European Parliament and of the Council of 11 December 2018 on the Promotion of the Use of Energy from Renewable Sources; European Parliament: Brussels, Belgium, 2018.

8. Walewicz, P. Greening the Critical Theory of International Relations with the Concept of World-Ecology. Torun Int. Stud. 2018, 1, 125-134. [CrossRef]

9. Walewicz, P. How international relations scholars explain the world: A world-ecological critique. Torun Int. Stud. 2019, 1, 51-60. [CrossRef]

10. World Commission on Environment and Development. Our Common Future: Report of the World Commission on the Environment and Development; Bruntlandt Report; General Assembly United Nations: Oxford, UK; New York, NY, USA, 1987.

11. Guijarro, F.; Poyatos, J.A. Designing a Sustainable Development Goal Index through a Goal Programming Model: The Case of EU-28 Countries. Sustainability 2018, 10, 3167. [CrossRef]

12. Krzyśko, M.; Wołyński, W.; Ratajczak, W.; Kierczyńska, A.; Wenerska, B. Sustainable Development of Polish Macroregions-Study by Means of the Kernel Discriminant Coordinates Method. Int. J. Environ. Res. Public Health 2020, 17, 7021. [CrossRef] [PubMed]

13. Raszkowski, A.; Bartniczak, B. On the Road to Sustainability: Implementation of the 2030 Agenda Sustainable Development Goals (SDG) in Poland. Sustainability 2019, 11, 366. [CrossRef]

14. Lenschow, A. (Ed.) Greening the European Union: An introduction. In Environmental Policy Integration: Greening Sectoral Policies in Europe; Earthscan: London, UK, 2002. 
15. Biermann, F.; Davies, O.; Van Der Grijp, N. Environmental policy integration and the architecture of global environmental governance. Int. Environ. Agreem. Politics Law Econ. 2009, 9, 351-369. [CrossRef]

16. Beunen, R.; van der Knaap, W.G.M.; Biesbroek, G.R. Implementation and integration of EU environmental directives. Experiences from The Netherlands. Environ. Policy Gov. 2009, 19, 57-69. [CrossRef]

17. Nilsson, M.; Persson, A. Framework for analysing environmental policy integration. J. Environ. Policy Plan. 2003, 5, 333-359. [CrossRef]

18. Sej-Kolasa, M. An environmental management system as an information system. Econ. Sociol. 2010, 3, 101-118. [CrossRef]

19. Lafferty, W.; Hovden, E. Environmental policy integration: Towards an analytical framework. Environ. Politics 2003, 12,1-22. [CrossRef]

20. Fergusson, M.; Collier, U. Energy and Environment in the European Union. Int. Aff. 1995, 71, 875. [CrossRef]

21. DeSombre, E.R. Domestic Sources of International Environmental Policy; MIT Press: Cambridge, MA, USA, 2000.

22. Falkner, R. The political economy of 'normative power' Europe: EU environmental leadership in international biotechnology regulation. J. Eur. Public Policy 2007, 14, 507-526. [CrossRef]

23. Kelemen, R.D. Globalizing European Union environmental policy. J. Eur. Public Policy 2010, 17, $335-349$. [CrossRef]

24. Calabro, G. The Eu-Policy of Promoting Green Purchases: The Role of Ecological Labelling. Forum Ware Int. 2007, 1, 1-7.

25. Jordan, A.; Jeppesen, T. EU Environmental policy: Adapting to the principle of subsidiarity? Eur. Environ. 2000, 10, 64-74. [CrossRef]

26. European Commission. Eco-Innovation at the Heart of European Policies; European Commission: Brussels, Belgium, 2020.

27. Kivimaa, P.; Mickwitz, P. The challenge of greening technologies—Environmental policy integration in Finnish technology policies. Res. Policy 2006, 35, 729-744. [CrossRef]

28. Kordana, S.; Słyś, D.; Dziopak, J. Rationalization of water and energy consumption in shower systems of single-family dwelling houses. J. Clean. Prod. 2014, 82, 58-69. [CrossRef]

29. Laperche, B.; Lefebvre, G.; Langlet, D. Innovation strategies of industrial groups in the global crisis: Rationalization and new paths. Technol. Soc. Chang. 2011, 78, 1319-1331. [CrossRef]

30. Pucar, M.; Pajevic, M.; Nenkovic, M. Intelligent buildings in context of energy rationalization. Spatium 2005, 12, 28-31. [CrossRef]

31. Tsuruda, L.K.; Rodrigues, L.; Salles, D.M.; Alves, A.J.; Calixto, W.P.; Vitor, L.R.; Souza, M.B.S.E. Energy Efficiency, Rationalization of Energy and Water Consumption in Popular Houses; Institute of Electrical and Electronics Engineers (IEEE): Piscataway, NJ, USA, 2017; pp. 1-6.

32. Shinn, L. Renewable Energy: The Clean Facts. Available online: https://www.nrdc.org/stories/renewableenergy-clean-facts (accessed on 30 August 2020).

33. Owusu, P.A.; Sarkodie, S.A. A review of renewable energy sources, sustainability issues and climate change mitigation. Cogent Eng. 2016, 3, 2-14. [CrossRef]

34. Lund, H. Renewable energy strategies for sustainable development. Energy 2007, 32, 912-919. [CrossRef]

35. Barry, M.-L.; Steyn, H.; Brent, A.C. Selection of renewable energy technologies for Africa: Eight case studies in Rwanda, Tanzania and Malawi. Renew. Energy 2011, 36, 2845-2852. [CrossRef]

36. Martinot, E.; Reiche, K. Regulatory Approaches to Rural Electrification and Renewable Energy: Case Studies from Six Developing Countries; Working Paper; World Bank: Washington, DC, USA, 2000.

37. Stigka, E.; Paravantis, J.A.; Mihalakakou, G.K. Social acceptance of renewable energy sources: A review of contingent valuation applications. Renew. Sustain. Energy Rev. 2014, 32, 100-106. [CrossRef]

38. O'Sullivan, M.; Overland, I.; Sandalow, D. The Geopolitics of Renewable Energy. SSRN Electron. J. 2017. [CrossRef]

39. Sequeira, T.N.; Santos, M.S. Renewable energy and politics: A systematic review and new evidence. J. Clean. Prod. 2018, 192, 553-568. [CrossRef]

40. Burke, M.J.; Stephens, J.C. Political power and renewable energy futures: A critical review. Energy Res. Soc. Sci. 2018, 35, 78-93. [CrossRef]

41. Kharlamova, G.; Chernyak, A.; Nate, S. Renewable energy and security for Ukraine: Challenge or smart way? J. Int. Stud. 2016, 9, 88-115. [CrossRef] [PubMed]

42. Suska-Szczerbicka, M. Wind energy financing tools. Econ. Soc. 2010, 3, 141-160. [CrossRef] 
43. Łucka, I.A. Economic and environmental aspects of renewable energy. Econ. Soc. 2010, 3, 119-140. [CrossRef]

44. Siemiatkowski, P. External financial security of the European Union member states outside the Eurozone. J. Int. Stud. 2017, 10, 84-95. [CrossRef]

45. Kasprowicz, R. Economic growth and CO2 emissions: The ECM analysis. J. Int. Stud. 2015, 8, 91-98. [CrossRef]

46. Kordonska, A.; Hurnyak, I. Efficient use of common resources in conditions of sustainable development. Torun Int. Stud. 2018, 1, 75-87. [CrossRef]

47. Jankowska, E. Social indicators and the measure of the quality of life. Torun Int. Stud. 2015, 1, 5. [CrossRef]

48. Szpak, A. Cities and human security. Torun Int. Stud. 2015, 1, 119. [CrossRef]

49. European Parliament. European Policies on Climate and Energy Towards 2020, 2030 and 2050; European Parliament: Brussels, Belgium, 2019.

50. European Parliament. European Commission DIRECTIVE 2009/28/EC OF THE EUROPEAN PARLIAMENT AND OF THE COUNCIL of 23 April 2009 on the Promotion of the Use of Energy from Renewable Sources and Amending and Subsequently Repealing; Directives 2001/77/EC and 2003/30/EC; European Parliament: Brussels, Belgium, 2009.

51. Forsal Jeśli Polska Nie Spełni Celu OZE, Kluczowe Staną Się Negocjacje z KE w 2021 Roku. Available online: https://forsal.pl/artykuly/1461014,brak-realizacji-celow-oze-pomoga-tylko-rozmowy-z-ke-w-2021roku.html (accessed on 30 August 2020).

52. Wróbel, P.; Ścigan, M. Co Się Stanie, Jeśli Polska Nie Osiagnie Celu OZE na 2020? Available online: https:// www.gramwzielone.pl/trendy/102673/co-sie-stanie-jesli-polska-go-nie-osiagnie-celu-oze-na-2020 (accessed on 30 August 2020).

53. Ministerstwo Rozwoju Polska i 7 Innych Państw UE Pisze do KE ws. Nowej Strategii Przemysłowej dla Europy i Wykorzystania OZE w Walce z Konsekwencjami COVID-19. Available online:

https://www.gov.pl/web/rozwoj/polska-i-7-innych-panstw-ue-pisze-do-ke-ws-nowej-strategiiprzemyslowej-dla-europy-i-wykorzystania-oze-w-walce-z-konsekwencjami-covid-19 (accessed on 30 August 2020).

54. SEJM. Ustawa Prawo Ochrony Środowiska, Ustawa z Dnia 26 Kwietnia 2001; Dz.U.2019.0.1396; SEJM: Warszawa, Poland, 2001.

55. Ministerstwo Rozwoju. Strategia na Rzecz Odpowiedzialnego Rozwoju do Roku 2020 z Perspektywa do Roku 2030; Ministerstwo Rozwoju: Warszawa, Poland, 2017.

56. Ministerstwo Aktywów. Państwowych Krajowy Plan na Rzecz Energii i Klimatu na Lata 2021-2030; Założenia i cele oraz polityki i działania; Ministerstwo Aktywów: Warszawa, Poland, 2019.

57. Ministerstwo Środowiska. Polityka Ekologiczna Państwa; Ministerstwo Środowiska: Warszawa, Poland, 2019.

58. BBN. Biała Księga Bezpieczeństwa Narodowego Rzeczypospolitej Polskiej; BBN: Warszawa, Poland, 2013.

59. SEJM. Ustawa o Samorządzie Województwa Ustawa z Dnia 5 Czerwca 1998 r. o Samorządzie Wojezództwa; Dz. U. z 2001, nr 142, poz. 1590, z późn. zm.: Warszawa, Poland, 1998.

60. GUS. Ekonomiczne Aspekty Ochrony Środowiska w 2018 r.; GUS: Warszawa, Poland, 2019.

61. EUROSTAT. Sustainable Development in the European Union. Monitoring Report on Progress towards the SDGs in an EU Context; European Union: Luxembourg, 2020.

62. GUS. Wskaźniki Zrównoważonego Rozwoju Polski; GUS: Warszawa, Poland, 2010.

63. Grabiński, T.; Wydymus, S.; Zielaś, A. Metody Taksonomii Numerycznej w Modelowaniu Zjawisk SpołecznoGospodarczych; PWN: Warszawa, Poland, 1989.

64. Kolenda, M. Taksonomia Numeryczna; Klasyfikacja, Porządkowanie i Analiza Obiektów Wielocechowych; Wydawnictwo Akademii Ekonomicznej we Wrocławiu: Wrocław, Poland, 2006.

65. Nowak, E. Metody Taksonomiczne w Klasyfikacji Obiektów Społeczno-Gospodarczych; PWE: Warszawa, Poland, 1990.

66. Zielaś, A. Ekonometria Przestrzenna; PWE: Warszawa, Poland, 1991.

67. Gierszewski, J.; Siemiątkowski, P.; Urbanek, A. Local Security in the Idea of Sustainable Development. Eur. Res. Stud. J. 2020, XXIII, 405-420. [CrossRef]

68. Siemiatkowski, P.; Tomaszewski, P.; Jurgilewicz, O.; Poplavska, Z. Assessment of basic elements of the security system of local communities. J. Secur. Sustain. Issues 2019, 617-635. [CrossRef]

69. Marszałek-Kawa, J.; Siemiatkowski, P. The implementation of the sustainable development goals at the local level: The case of the districts of Kuyavian-Pomeranian province. Balt. J. Econ. Stud. 2020, 6, 1-8. [CrossRef]

70. Siemiątkowski, P.; Tomaszewski, P. Poczucie bezpieczeństwa członków społeczności lokalnych na przykładzie województwa kujawsko-pomorskiego. Przedsiębiorczość Zarządzanie 2018, XIX, 157-173. 
71. Ostasiewicz, W. Statystyczne Metody Analizy Danych; Wydawnictwo Akademii Ekonomicznej we Wrocławiu: Wrocław, Poland, 1998.

72. Dworczyk, M. Analyzes of the Division of the Voivodeship Mazowieckie are Advanced. Available online: https://www.world-today-news.com/michal-dworczyk-analyzes-of-the-division-of-the-voivodeshipmazowieckie-are-advanced/ (accessed on 14 October 2020).

73. Siemiatkowski, P.; Jankowska, E. Measuring the Progress in Realizing the Strategy “Europe 2020" in 2010-2016 in 28 European Union Member States. Pol. Politics Sci. Yearb. 2020, 49, 11-31. [CrossRef]

Publisher's Note: MDPI stays neutral with regard to jurisdictional claims in published maps and institutional affiliations.

(C) 2020 by the authors. Licensee MDPI, Basel, Switzerland. This article is an open access article distributed under the terms and conditions of the Creative Commons Attribution (CC BY) license (http://creativecommons.org/licenses/by/4.0/). 